\title{
The Theoretical Reflection of Islamo-Fascism and Darul Islam Movement in Indonesia
}

\author{
Al Chaidar ${ }^{1}$, Teuku Syahrul Ansari ${ }^{2}$, Irfan Iryadi $^{2}$, Dedy Tabrani ${ }^{3}$ \\ ${ }^{I}$ Malikussaleh University, Lhokseumawe, Aceh, Indonesia \\ ${ }^{2} \mathrm{PhD}$ Candidate, University of Diponegoro Semarang, Indonesia \\ ${ }^{3}$ Police Science College (PTIK, Perguruan Tinggi Ilmu Kepolisian), Jakarta, Indonesia
}

\begin{abstract}
This study regarding the theoretical reflection of Islam-fascism and Darul Islam movement in Indonesia. History of Islam in Indonesia is also the history of power struggle (caliphate) which has not been completed until now. At that time Islam respecting plurality and respect the existing culture. The spirit of pluralism and tolerance enforced developed with enriched intellectual repertoire. Increasingly repressive and hegemonic states, bulldoze people across ethnic, class, and layers. Political regimentation of Suharto's New Order devastated spirit of nationality and humanity. Therefore, the intellectuals and the elite of Islam must find a way out of the crises of social, economic, and political ideology today, so that no reform has stagnated, so that this nation does not disintegrate. Giddens called political "third way" to emphasize the "no rights without responsibilities". In the era of the Prophet of Islam, "no rights without responsibilities" that accentuated in the Medina Charter, which guarantees the freedom, equality and justice. In the Islamic era Cordova, Spain, spirit and conception" Medina Charter" that then make their community a pluralistic, cosmopolitan, multicultural and universal, so they are willing to learn and accept everything of value from the experiences of other communities.
\end{abstract}

Keywords: Islamo-fascism; Darul Islam; Indonesia

\section{Introduction}

Fascism is the one form of government with the most disagreement about a definition for it. However, Passmore (2002) attempts a definition as the consolidation of an ultranationalist ideology that is unabashedly racist. The word comes from the Latin "fasces" which means to use power to scare or impress people. It generally refers to the consolidation of all economic and political power into some form of super-patriotism that is devoted to genocide or endless war with one's enemies. Benito Mussolini, who practically invented the term in 1922, said it is the merger of state and corporate power. Mussolini's version of fascism was based on the idea of an indomitable power and an attempt to resurrect imperial Rome.

Adolf Hitler said fascism is the clever and constant application of propaganda so that people can be made to see paradise as hell, and the other way around. Hitler's brand of fascism drew upon philosophical reflections by Hegel, Nietzsche, and Spengler, and also drew upon Nordic folk romance from Wagner to Tacitus. Japanese fascism involved racism, fanaticism, historical destiny, and a mixture of Bushido, Zen and Shinto Buddhism, emperor worship, and past samurai legends.

So-called Islamo-Fascism can be traced to the time period of the birth of Nazi "national socialist" fascism in 1928 when the Muslim Brotherhood (Al Ikhwan Al Muslimun), parent 
Konfrontasi Journal: Culture, Economy and Social Changes, 6 (2) July 2019, 31-36

P-ISSN: 1410-881X (Print)

Al Chaidar, Teuku Syahrul Ansari, Irfan Iryadi, Dedy Tabrani: The Theoretical Reflection of Islamo-Fascism and Darul Islam Movement in Indonesia

DOI: -

http://www.konfrontasi.net/index.php/konfrontasi2

organization of numerous terrorist groups, was formed in reaction to the 1924 abolition of the caliphate by the Turks. Islamofascism draws heavily upon the Muslim Brotherhood pamphleteers, but also upon on the Koran, the career of Saladin, and the tracts of Nasserites and Baathists. The term, "Islamic Fascism" is a better term to use, best describing the agenda of contemporary radical Islam. It captures the twin thrusts of reactionary fascism today. In one sense, fascism is born out of insecurity and a sense of failure, but in another sense, fascism thrives in a once-proud, humbled but ascendant, people. Envy and false grievance are the trademarks of such reactionary fascism. Believers are subject to all kinds of conspiratorial delusions that setbacks were caused by others and can be erased through ever more zealotry. Fascist leaders love conspiracies and lies; nothing they say should be trusted.

Darul Islam is an Islamist group that fought for the establishment of an Islamic state in Indonesia. It was established in 1942 by a group of Muslim militias, coordinated by a charismatic radical Muslim politician, Sekarmadji Maridjan Kartosoewirjo. The group recognized only Shari'a as a valid source of law. The movement has produced splinters and offshoots that range from Jemaah Islamiyah to non-violent religious groups. During the Indonesian National Revolution, Kartosoewirjo founded his own band of fighters in West Java, called Hizbullah and Sabilillah. As a protest toward the Renville Agreement signed by Indonesian leaders in 1948, which ceded West Java to the Dutch, Kartosoewirjo proclaimed a Darul Islam (meaning "Islamic State") in West Java on August 7, 1949. Darul Islam did not disband itself after the transfer of sovereignty in 1949, resulting in a clash with the government of the Indonesian Republic.

\section{Review of Literature}

Fascism is full of ironies and contradictions. On the one hand, it is anti-modern in its glorification of the land, a return to country life, and its fascination with peasant dress or costume. On the other hand, it is pro-modern in its worship of military technology, favoritism of big business, mass mobilization of people, promotion of commercialized sport, and its surprisingly liberal attitude toward the involvement of women in the movement. Science and scholarship also take on interesting twists under fascism. "Hard" sciences like biology and chemistry usually advance significantly, especially in areas such as genetic research. "Soft" sciences like sociology and psychology usually become usurped into mumbo-jumbo pseudoscientific ideas about a glorified folk culture and reasons for hating the enemy.

Just as anarchists have their May Day (May 1st) celebrations, fascists also tend to celebrate anniversaries. Many terrorists, of course, have been known to time their attacks to coincide with the date for an historical event or the birthday of someone special to them. For example, with ecoterrorism, that day is October 16, which coincides the the United Nation's World Food Day, and is usually when McDonald's restaurants are targeted for vandalism. However, the most important date in the study of terrorism is April 19.

A number of significant events have happened on that date. Right-wing domestic terrorist groups call it "Militia Day" because it was when the siege at Waco ended, it was when surveillance began at the Ruby Ridge compound in Idaho, and it marks the anniversary of the Oklahoma City bombing of the federal building. Neo-Nazi fascist groups celebrate April 19 because it was the day German Nazis started wiping out Jewish ghettos across Europe, as well as the following day being Adolf Hitler's birthday. Internationally, terrorist 
Konfrontasi Journal: Culture, Economy and Social Changes, 6 (2) July 2019, 31-36

P-ISSN: 1410-881X (Print)

Al Chaidar, Teuku Syahrul Ansari, Irfan Iryadi, Dedy Tabrani: The Theoretical Reflection of Islamo-Fascism and Darul Islam Movement in Indonesia

DOI: -

http://www.konfrontasi.net/index.php/konfrontasi2

groups who regard themselves as "freedom fighters" and trace at least part of this justification to the American Revolution, take heart in the fact that the American Revolution started on April 19, 1775 at the Battle of Lexington. It remains to be seen if September 11 will replace April 19 as the most popular date for terrorism.

Darul Islam (meaning House of Islam), also known as Darul Islam/Islamic Armed Forces of Indonesia (Indonesian: Darul Islam/Tentara Islam Indonesia, DI/TII), was an Islamist group that fought for the establishment of an Islamic state in Indonesia. It was established in 1942 by a group of Muslim militias, coordinated by a charismatic radical Muslim politician, Sekarmadji Maridjan Kartosoewirjo. The group recognised only Shari'a as a valid source of law. The movement has produced splinters and offshoots that range from Jemaah Islamiyah to non-violent religious groups.

\section{Discussion}

With the arrest of the alleged perpetrators of terrorism in Indonesia and in Southeast Asian countries and even in America and Europe, more and shows us that the terrorist organization's network is very extensive. Although morally and international diplomacy terrorists attacked the "war discourse" that discredit them as "the coward" , "the brute" , "people who are happy at the expense of others" , and "the tendency of the mental illness", but the terrorists are constantly emerging in the political map of Indonesia and the world until now to convey messages that are very difficult to interpret.

So this one is a hidden enemy, has created the impression of mystery and psychological fear itself. For the American people, a terrorist is a ghost ( Specter ) who had faced the U.S. after the ghost of communism, a form of ideological enemies, as well as the new spiritual enemies ever be treated by reminding Huntington in The Clash of Civilization . Douglas E. Streusand even dare to mention "that Specter is Islam", which was later identified in layman by the U.S. public as the "green peril" (green hazard). And, with the events of the attack on the WTC and the Pentagon two years ago, the name of Osama bin Laden emerged as the "enemy" to restore the confidence of the American public against the government in dealing with terrorism from Muslims.

In the context of Indonesia as the largest Muslim country in the world, the problem of terrorism has raised many dilemmas: between keeping the feelings of Muslims and law enforcement that must be enforced. More than that, there is a fact that there has been a brutal attack and the enemy must be defined to then take further steps before executing the 'criminals' who despite continuing to hide behind the symbols and religious reasons. To determine the theoretical context of the emergence of "terrorists", have listened to the development of thinking in Islamic fundamentalism.

Ideologically, among Indonesian Muslims, especially after the Reformation Period (1999 - now) discourse about the caliphate, Islamic state, jihad, allegiance to the study of the Charter of Medina and Medina State, not a stranger. Since this period many radical movements and fundamentalist movements turn into terrorists. They have monopolized the interpretation of discourse about the state of Islam, caliphate, these terms jihad and Islamic politics. In the era of President Abdurrahman Wahid, the discourse about the Islamic state spread on college campuses, the Islamic movements and activists mosque. About the caliphate, Islamic state Madinah to the study of the State is, perhaps, only one of the most 
Konfrontasi Journal: Culture, Economy and Social Changes, 6 (2) July 2019, 31-36

P-ISSN: 1410-881X (Print)

Al Chaidar, Teuku Syahrul Ansari, Irfan Iryadi, Dedy Tabrani: The Theoretical Reflection of Islamo-Fascism and Darul Islam Movement in Indonesia

DOI: -

http://www.konfrontasi.net/index.php/konfrontasi2

ideal Islamic state, the State Medina with its Charter of Madinah during the Prophet Muhammad SAW (VII century). However, for most people, the Medina State is almost like a "fairy tale" even exist in history.

To avoid "mythologyzation", then we need to examine the Islamic state has ever appeared in the heart of Europe: Spain Islamic era (Islamic Spain). Muslim countries and Muslims in Spain is one of the most remote areas of the world the heart of Islam, but very tolerant. Bernard Lewis suggests that early Islam was, apparently tend to be more tolerant than Islam is more recent. At the beginning of the Islamic period, a lot of social interaction that takes place smoothly between Muslims, Christians, and Jews. Although embrace different religions, they form a single community, where interpersonal friendship, partnership in business, teacher-student relationships in the life sciences, and other forms of normal activities with other ongoing and even very common.

\subsection{Fascism}

Fascism supports terrorism at home and abroad. Charismatic leaders are usually given supreme powers to crack down on dissidents, peacemakers, and anyone who doesn't abide by the "cult of the individual" which worships a He-man mentality and the party line. With the frequent wars and militaristic ventures that come with fascism, an effort is made to demonize the enemy as sub-humans who deserve extinction. These enemies are also made into scapegoats for all the past problems a country has had. Fascism appeals to the frustrations and resentments of a race of people who think they ought to have a bigger place at the global table. When combined with an anti-western slant (the United States as Great Satan), fascism becomes a means of social identity (Pan-Africanism, Pan-Arabism, Islamo-Fascism) as well as a facilitator of terrorism.

Frustrated fascists who fail to gain control in their own countries have historically turned to terrorism. They are most likely to turn to domestic terrorism since fascists do not believe that citizen rights are bestowed merely because someone inhabits a country. Nor do they believe that all human beings are possessed of equal rights. "Foreign" families and businesses (as they define them) are usually targeted for extermination by fascists. The enemies who are seen as the greatest threat are usually those who fascists see as corrupting or poisoning family and property relations.

\subsection{Darul Islam Movement}

Historically, if we look at how the Darul Islam (DI) Movement proliferated and build a radical ideology in managing its survival movement in Indonesia, then we can trace the connection of terrorism with the Darul Islam movement in the early 21 th century.

In their tradition that there once was a tradition of free and critical thinking within is Islam, called ijtihad (concept of creative reasoning) has a track record. In the early decades of the emergence of Darul Islam (DI), three schools of thought flourished, the Kamil Hanafi, the Masduki and the Abdullah Sungkar school of thought. In Masdukian and Sungkarian, scholars would teach their students to abandon "expert" opinions about the Qur'an if their own conversations with the ambiguous book produced more compelling evidence for their "peaceful" ideas.

And the Kamilan, among the most sophisticated Sufi school in Islamic Indonesia, had 70 literatures as outcome of their thoughtful exercise. But, only Masdukian and Sungkarian who 
Konfrontasi Journal: Culture, Economy and Social Changes, 6 (2) July 2019, 31-36

P-ISSN: 1410-881X (Print)

Al Chaidar, Teuku Syahrul Ansari, Irfan Iryadi, Dedy Tabrani: The Theoretical Reflection of Islamo-Fascism and Darul Islam Movement in Indonesia

DOI: -

http://www.konfrontasi.net/index.php/konfrontasi2

then developed a more radical and a more fundamentalist sense of struggling Islam in Indonesia and that is one for every virgin that today's Muslim martyrs believe Allah pledges them.

\section{Conclusion}

Muslim history, like the history of any community of human beings, always has the potential to make a mistake or turn from the right path. In addition to the simple truism as the English poet Alexander Pope said, all by itself is a clear history of human history, and no ordinary human being is sacred and holy. History of Islam in Indonesia is also the history of power struggle (caliphate) which has not been completed until now. Efforts to realize the power it has implications for the emergence of insurgency (DI/TII 1949) to terrorism (1999 to present).

At that time Islam respecting plurality and respect the existing culture. The spirit of pluralism and tolerance enforced developed with enriched intellectual repertoire. However, under Suharto's New Order, all of them have cracks: state building has been exceeded and destroy nation building. Increasingly repressive and hegemonic states, bulldoze people across ethnic, class, and layers. Political regimentation of Suharto's New Order devastated spirit of nationality and humanity.

Therefore, the intellectuals and the elite of Islam must find a way out of the crises of social, economic, and political ideology today, so that no reform has stagnated, so that this nation does not disintegrate. Giddens called political "third way" to emphasize the "no rights without responsibilities". In the era of the Prophet of Islam, "no rights without responsibilities" that accentuated in the Medina Charter, which guarantees the freedom, equality and justice. In the Islamic era Cordova, Spain, spirit and conception" Medina Charter" that then make their community a pluralistic, cosmopolitan, multicultural and universal, so they are willing to learn and accept everything of value from the experiences of other communities.

\section{References}

Brackenridge, Linda G. "The Darul Islam movement in West Java: A study of religion and its relationship to insurgency." PhD diss., Australian National University, 1975.

Bruinessen, M. van. "The Violent Fringes of Indonesia's Islam." ISIM Newsletter 11 (2002): 7.

Burhanuddin, N. (2010). Tipologi Gerakan Sempalan di Kalangan Umat Islam Indonesia: Analisis Sosiologi dan Fungsional.

Cooper, H. H. A. 2001. "Terrorism: The Problem of Definition Revisited." American Behavioral Scientist 44: 881-893.

Crenshaw, Martha. 1981. "The Causes of Terrorism." Comparative Politics 13: 379-99

Dengel, Holk. "Darul Islam dan kartosuwirjo:'Angan-Angan yang Gggal (Darul Islam and kartosuwirjo:'The illusion that failed')." (1995).

Dijk, Cornelis. Darul Islam: sebuah pemberontakan. Pustaka Utama Grafiti, 1987.

Dijk, Cornelis. Rebellion under the banner of Islam: the Darul Islam in Indonesia. The Hague: Martinus Nijhoff, 1981. 
Konfrontasi Journal: Culture, Economy and Social Changes, 6 (2) July 2019, 31-36

P-ISSN: 1410-881X (Print)

Al Chaidar, Teuku Syahrul Ansari, Irfan Iryadi, Dedy Tabrani: The Theoretical Reflection of Islamo-Fascism and Darul Islam Movement in Indonesia

DOI: -

http://www.konfrontasi.net/index.php/konfrontasi2

Eisenstein, Hester. 2001. "After 9/11: Globalization and the Events of September 11, 2001." Journal of the Research Group on Socialism and Democracy 16: 131136.

Eliraz, Giora. Islam and Polity in Indonesia: An Intriguing Case Study. Hudson Institute, 2007.

Enders, Walter and Todd Sandler. 2006. The Political Economy of Terrorism. New York: Cambridge University Press.

Fealy, Greg, and Greg Barton, eds. Nahdlatul Ulama, traditional Islam and modernity in Indonesia. No. 39. Monash Asia Inst, 1996.

Gibson, Thomas. "Islam and the spirit cults in new order Indonesia: Global flows vs. local knowledge." Indonesia 69 (2000): 41-70.

Glubb, Sir John Baggot. 1957. A Soldier with the Arabs. New York: Harper and Row.

Goodwin, Jeff. 2006. "A Theory of Categorical Terrorism.” Social Forces 84: 2027-2046.

Goolsby, Rebecca. "Combating terrorist networks: An evolutionary approach." Computational \& Mathematical Organization Theory 12, no. 1 (2006): 7-20.

Gunaratna, R. (2005). The Ideology of Al-Jama'ah Al-Islamiya. Current Trends in Islamist Ideology, 68, 68-81.

Gunn, Geoffrey C. "Radical Islam in Southeast Asia: Rhetoric and Reality in the Middle Eastern Connection." Journal of Contemporary Asia 16, no. 1 (1986): 30-54.

Haddad, S. and Khashan, H. (2002) Islam and terrorism. Journal of Conflict Resolution 46: 812-828.

Kolig, E. (2005). Radical islam, islamic fervour, and political sentiments in central java, Indonesia. European Journal of East Asian Studies, 4(1), 55-86.

Kuper, Leo, Genocide. 1981. Harmondsworth: Pelican Books.

Laffan, Michael. "The tangled roots of Islamist activism in southeast asia." Cambridge Review of International Affairs 16, no. 3 (2003): 397-414.

Laqueur, Walter. 1977. Terrorism. London: Weidenfeld and Nicolson.

Lee, Martha F. The nation of Islam: an American millenarian movement. Syracuse University Press, 1996.

Lenin, V. I. 1971. State and Revolution. New York: International Publications.

Liong, Liem Soei. "Indonesian Muslims and the state: Accommodation or revolt?." Third World Quarterly 10, no. 2 (1988): 869-896.

Lizardo, Omar. 2008. "Defining and Theorizing Terrorism: A Global Actor-Centered Approach.” Journal of World-Systems Research, Vol. XIV: 91-118.

Mackie, J. A. C. "Integrating and centrifugal factors in Indonesian politics since 1945." Indonesia: the Making of a Nation 2 (1980): 669-84.

Magouirk, Justin, Scott Atran, and Marc Sageman. "Connecting terrorist

Temby, Q. (2010). Imagining an Islamic State in Indonesia: From Darul Islam to Jemaah Islamiyah. Indonesia, (89), 1-36.

Temby, Quinton. "Imagining an Islamic State in Indonesia: From Darul Islam to Jemaah Islamiyah." Indonesia 89 (2010): 1-36.

Van Bruinessen, Martin. "State-Islam Relations in contemporary Indonesia; 1915-1990." State and Islam. Leiden: Research School CNWS (1995).

Walzer, Michael. 1977. Just and Unjust Wars: A Moral Argument with Historical Illustrations. New York: Basic Books. 